\title{
Environmental Concern as an Underlying Mechanism between Environmental Beliefs and Green Purchase Intentions
}

\author{
Israr Ahmad * $\quad$ Fauzia Syed ${ }^{\dagger} \quad$ Saima Naseer ${ }^{\ddagger} \quad$ Ghulam Rasool $\S$
}

\begin{abstract}
Building on the contentions of theory of reasoned action, current study hypothesized and tested the direct impact of environmental beliefs on green purchase intentions. In addition, the mediating role of environmental concern between environmental beliefs and green purchase intentions is also explored. Quantitative research design with survey method was adopted to collect data from respondents. Structural Equation Modeling (SEM) technique was used to gauge the model fit and to test the hypothesized associations. The results reveal that environmental beliefs are positively related to green purchase intentions. Moreover, environmental concern mediate the relationship between environmental beliefs and green purchase intentions. Managerial implications and future research directions are corroborated at the end of the paper.
\end{abstract}

Keywords: Environmental beliefs, environmental concern, green purchase intentions

\section{Introduction}

The notion of green marketing and green consumptions came in to existence when rapid changes in the environment in the form of global warming, unavailability of clean water, changing weather conditions, degradation of land, damage to ozone layer, reduction of flora \& fauna and increasing pollution are recognized and subsequently concern was expressed by the consumers (Manget, Roche, \& Münnich, 2009). Green Marketing includes marketing processes and activities of developing and selling products and services based on environmental benefits (Chen, 2010; Grewal \& Levy, 2008). The voice for the protection of natural environment is increasing day by day to overcome its negative effects on future generations (Davari \& Strutton, 2014). Thus, increasing pressure from consumers along with international regulatory bodies have made a large number of firms to revisit their business models in order to incorporate the green marketing elements (Grimmer \& Woolley, 2014; Pagiaslis \& Krontalis, 2014; Straughan \& Roberts, 1999).

Many business firms start offering green products by recognizing it an aggressive move to take a competitive advantage in the market place (Chen \& Chang, 2013; Luo \& Bhattacharya, 2006). Several organizations spent millions of dollars on the development, selling and on promotional campaigns of green products (D'Souza, Taghian, Sullivan-Mort, \&

\footnotetext{
*PhD Scholar, International Islamic University Islamabad, Pakistan. E-mail: hafiz.israr@gmail.com

${ }^{\dagger}$ Assistant Professor, International Islamic University Islamabad, Pakistan. E-mail: fauzia.syed@iiu.edu.pk

¥Assistant Professor, International Islamic University Islamabad, Pakistan. E-mail: saima.naseer@iiu.edu.pk

$\S$ PhD Scholar, International Islamic University Islamabad, Pakistan. E-mail: grwsc@yahoo.com
} 
Gilmore, 2015; Dunlap \& Van Liere, 1978; Menguc, Auh, \& Ozanne, 2010). These efforts were augmented by researchers and survey organizations in which growing demand of green products was predicted (Schmeltz, 2012; Widger, 2007). Prior research claimed that by 2015, market of green products will be increased approximately in value up to $\$ 845$ billion (Tolliver-Nigro, 2009). Similarly in a study $83 \%$ of consumers express that environmental factor have an impact on their purchase decisions (Wire, 2011). Likewise, survey by Euromonitor-International (2012) revealed that "53 per cent of the total 15,933 respondents" consider environment as an essential aspect while making a buying decision. Even consumers are prepared to pay extra money for buying green products from those organizations which are taking measures to protect the environment and natural resources (Chen \& Chang, 2013; Lung, 2010; Veisten, 2007). An extant literature highlighted the growing concern of consumers towards environmental hazards (Akehurst, Afonso, \& Martins Gonçalves, 2012; California-Green-Solutions, 2007; Hartman, 2007) and intentions to purchase the green products (Cooney, 2010; Saad, 2006).

Despite the above-mentioned facts, recent surveys and research in the field of green marketing have highlighted that engagement of consumers in green marketing campaigns and adoption of green products is still an unresolved issue (Barbarossa \& Pastore, 2015; González, Felix, Carrete, Centeno, \& Castaño, 2015; Johnstone \& Tan, 2015). Prior research reveals that actual market share of green products varies between $1 \%$ to $6 \%$ (Nielsen, 2013) and majority of consumers are not intended towards the adoption of green products (Biswas \& Roy, 2015; Moser, 2015). Though, consumers are in favor of green products and appreciate green organizations for their initiatives taken to protect the environment however, when it comes to make a purchase decision, conventional products remain their first choice in most of the deals (Hughner, McDonagh, Prothero, Shultz, \& Stanton, 2007; Johnstone \& Tan, 2015; Vermeir \& Verbeke, 2008; Young, Hwang, McDonald, \& Oates, 2010). Thus, non-acceptance of green products by the consumers' at large scale is becoming a major issue of concern for practitioners (Barbarossa \& Pastore, 2015; Gleim, Smith, Andrews, \& Cronin Jr, 2013; Johnstone \& Tan, 2015). It is therefore very timely to propose and test the reasons/mechanisms of this failure because without a greater understanding of stakeholders and consumer perceptions, firms may not likely to reap the financial rewards associated with green marketing strategies (Leonidou \& Skarmeas, 2017; Thieme, Royne, Jha, Levy, \& Barnes McEntee, 2015; Vezich, Gunter, \& Lieberman, 2017).

Several factors have been acknowledged which influence the consumers' green purchase intentions (Fetterman, 2006); however, still research is needed to develop effective mechanisms which can help the marketing managers to reduce the attitude-behavior gap in market place (Barbarossa \& Pastore, 2015; Joshi \& Rahman, 2015; Pagiaslis \& Krontalis, 2014; Xiao \& McCright, 2015). The new research streams may include the mediating and moderating role of different variables in conceptual models to build inclusive understanding of complicated relationship between consumer attitude and green purchase intentions (X. Liu, Wang, Shishime, \& Fujitsuka, 2012; Ozaki \& Sevastyanova, 2011). In prior research environmental beliefs has been taken as an antecedent of green purchase intention (Gadenne, Sharma, Kerr, \& Smith, 2011; Mainieri, Barnett, Valdero, Unipan, \& Oskamp, 1997). However, some of the authors in prior research studies have pointed out a weak relationship between environmental beliefs and green purchase intention (Bamberg, 2003; 
Pickett-Baker \& Ozaki, 2008). It is therefore suggested that predictive ability of environmental beliefs should be assessed along with the mediating variables (Corral-Verdugo, Bechtel, \& Fraijo-Sing, 2003; Gadenne et al., 2011; Ozaki \& Sevastyanova, 2011) so that accurate picture of consumer trends and patterns concerning the green markets and green purchase intentions may be tapped. Current research is an effort to respond these calls for research by exploring the mediating role of environmental concern (EC) between environmental beliefs (EB) and green purchase intentions (GPI). Prior research has reported a significant influence of environmental concern on individuals' motivation to behave in a way that can alleviate environmental problems (Joshi \& Rahman, 2015; Nath, Kumar, Agrawal, Gautam, \& Sharma, 2013). Especially, the role of environmental concern is more crucial in developing countries (Lin \& Syrgabayeva, 2016) because without inducing environmental concern, consumers may not be inclined to take interest in green marketing campaigns and green products (Olson, 2013; Suki, 2016). It is therefore worthwhile to identify the existing level of environmental concern of consumers as well as the ways through which environmental concern can be raised for the success of green marketing campaigns (Suki, 2016).

A great deal of research in the field of green marketing has been conducted in developed countries whereas, only a small portion is owned by the authors of developing nations. However, understanding the nature of consumers of developing nations is as much significant as it is considered for developed nations. There are different facets which make studies from developing nations worthy and inevitable. First, the effects of environmental degradation issued are producing more drastic results for developing nations as compare to developed countries. For example, Pakistan is ranked at number eight amongst the countries which are severely affected due to environmental changes (Khan, 2016). Second, residents of developing nations are considered to be more environmentally concerned as compare to the residents of developed nations (Lo, 2016). Therefore, consumers of developing countries may provide great business opportunities for green products if careful communication plans are prepared to target the different market segments. Third, most of the developing nations are emerging markets due to huge population which can provide an opportunity to business organizations to reap financial benefits by introducing certain green products and services. Fourth, the generalizability of results may not be claimed till evaluation of buying patterns of consumers of developing countries such as Pakistan where the concept of green marketing is relatively new as compare to the developed countries. Hence, the findings of research conducted in developing nations could be very helpful for marketing managers to understand the complex nature of human attitudes and attitude formation process. Subsequently, such understanding may enable them to devise effective marketing plans and communication strategies to involve the consumers in green consumption behaviors.

\section{Literature Review}

\section{Theory \& Hypothesis Development}

The conceptual framework for current study is developed by using the theory of Reasoned Action (Fishbein \& Ajzen, 1975) which is widely used by authors in green marketing 
literature to study the behavioral intentions of consumers (Cronin Jr, Brady, \& Hult, 2000; Paço \& Lavrador, 2017; Pagiaslis \& Krontalis, 2014). According to the theory of reasoned action, consumer intention to execute a behavior is a function of attitudes and subjective norms. Prior research reveals that attitudes are more predictive of behavior intentions as compare to the subjective norms (Trafimow \& Fishbein, 1994). The scope of current study is to explore the proposed relationship among the attitudinal variables therefore subjective norms are not given due consideration. Several authors in prior studies have already used the theory of reasoned action in similar way (Bang, Ellinger, Hadjimarcou, \& Traichal, 2000). Thus, theory of reasoned action has been used for current research study as a foundation to explain the association between environmental beliefs, environmental concern and green purchase intentions. It is proposed that strong environmental beliefs may induce environmental concern which, in result, may influence the consumer green purchase intentions.

\section{Relationship of Environmental Beliefs with Environmental Concern and Green Purchase Intentions}

Environmental beliefs are conceptualized as the extent to which individuals have awareness of environmental degradation issues which enable them to realize the effects of such environmental degradation issues on human lives (Guber, 2003). Similarly, environmental concern can be conceptualized as the extent to which individuals are willing to support the activities and efforts related to confront the environmental degradation issues (Kim \& Choi, 2005). Likewise, green purchase intentions can be conceptualized as the extent to which consumers are willing to purchase/ prefer a product having eco-friendly features (Oliver \& Lee, 2010). A number of researchers and practitioners have recognized the importance of inducing intentions of consumers towards a product or service (Namkung \& Jang, 2017; Wu, Wu, Lee, \& Lee, 2015).

Environmental beliefs are considered to be a driving force which may provide a guideline to public to act in an environmental friendly way by changing their perceptions with the passage of time (McCarty \& Shrum, 2001). The results of prior research reveals that consumers with stronger pro-environmental beliefs are more likely to engage in environmental oriented purchasing behavior (Mainieri et al., 1997; Pickett-Baker \& Ozaki, 2008). Similarly, prior research also indicates that consumers' possessing positive environmental beliefs may exhibit a consistent response towards green products or services in terms of purchase intentions thus providing an opportunity to marketing managers to easily capture such market segment by carefully formulating and executing the marketing strategies (D'Souza, Taghian, \& Khosla, 2007). The perceptions of public towards the significance of environmental problems may vary across the cultures with respect to geographic regions, level of education, awareness, intensity and economic conditions of country (Anderson, Romani, Phillips, Wentzel, \& Tlabela, 2006; Barber, 2010; Do Paco \& Raposo, 2009; Harris, 2006; Mina Okada \& Mais, 2010). These differences may affect differently to the residents of that particular region to express their concern towards the environmental problems and their possible solutions (Dunlap et al., 1994). Research reveals that population in Asian countries is more concerned with environmental problems as compare to population 
of western nations (Cherian \& Jacob, 2012). Hence specific environmental beliefs held by consumers significantly affect their concern towards the environment. Following hypothesis are proposed based on the above discussions:

$H_{1}$ : Environmental beliefs have a positive association with green purchase intentions.

$\mathrm{H}_{2}$ : Environmental beliefs have a positive association with environmental concern.

\section{Relationship of Environmental Concern with Green Purchase In- tentions}

Prior research reveals that when consumers are highly concerned about the environment, they are more likely to evaluate the effects of their purchases on the environment (Follows \& Jobber, 2000; Nath et al., 2013). Thus, such consumers may be more inclined towards the adoption of green consumption behaviors (Kilbourne \& Pickett, 2008). Generally, a positive correlation has been found between environmental concern and environmentally friendly behavior (Kalafatis, Pollard, East, \& Tsogas, 1999; Laroche, Bergeron, \& BarbaroForleo, 2001; Manaktola \& Jauhari, 2007; Straughan \& Roberts, 1999). Likewise Bang et al. (2000) confirm in their study that consumers, who are more concerned about the environmental issues, express more willingness to pay higher prices for renewable energy than those who are less concerned. Kim and Choi (2005) point out that it is much more probable that people who are highly concerned about environmental issues will purchase environmentally friendly products than those who are less concerned. Hence following hypothesis is proposed based on the above discussions:

$H_{3}$ : Environmental concern has a positive association with green purchase intentions.

\section{Mediating Role of Environmental Concern between Environmental Beliefs and Green Purchase Intentions:}

A stream of existing research is continuously trying to investigate the potential factors which can explain a significant and positive change in consumers green purchase intentions. Many authors have developed theoretical models by introducing different variables which may influence the consumers, directly or indirectly, while making a decision to purchase a green product or service (Cowan \& Kinley, 2014; Griskevicius, Tybur, \& Van den Bergh, 2010; Ha \& Janda, 2012; Kang, Liu, \& Kim, 2013; Pagiaslis \& Krontalis, 2014). Past studies reveal that environmental beliefs may not be a strong predictor of green purchase intentions (Pickett-Baker \& Ozaki, 2008). There are other research studies in which authors have pointed out the environmental beliefs as an indirect predictor of specific proecological behaviors and suggested that predictive ability of environmental beliefs should be assessed along with the mediating variables (Corral-Verdugo et al., 2003; Gadenne et al., 2011) so that accurate picture of consumer trends and patterns concerning the green markets and green purchase intentions may be tapped. Therefore, it is proposed that environmental concern mediate the relationship between environmental beliefs and green purchase intentions. Logically, if environmental beliefs of consumers are not strong they 
may not be able to demonstrate their concern for environment (Kim \& Choi, 2005; PickettBaker \& Ozaki, 2008; Suki, 2016) and consequently, such consumers may not prefer the green products nor they will give attention to increasing intensity of environmental hazards. Raising environmental concern is increasingly becoming important for the success of business firms in emerging markets (Wray-Lake, Flanagan, \& Osgood, 2010). Research also suggest that positive environmental beliefs affect the environmental concern and ultimately such consumers are expected to be more inclined towards the purchase of green products (Kilbourne \& Pickett, 2008; Knopman, Susman, \& Landy, 1999). Similarly, the results of prior research reveal that without environmental concern, consumers may not be intended towards the purchase of green products (Lee, 2009; Ling-Yee, 1997; Sinnappan \& Rahman, 2011). The current study also proposes that the effect of environmental concern on green purchase intentions depends upon the environmental beliefs held by the consumers regarding the seriousness of environmental degradation issues. Hence following hypothesis is proposed based on the above discussions:

$H_{4}$ : Environmental concern mediates the relationship between environmental beliefs and green purchase intentions.

\section{Methodology}

The current study is based on the quantitative research design. Survey method was used for data collection from the respondents residing in two main cities of Pakistan i.e. Rawalpindi and Islamabad. Self-administered questionnaire was used as survey instrument to collect data from the respondents of the study. The major benefits of this survey method are less cost and minimal interference of researcher (Malhotra, 2007). The researchers' minimal interference reduces the response bias. Convenience sampling technique was used for data collection in line with prior research studies (Konuk, Rahman, \& Salo, 2015; Nguyen, Lobo, \& Greenland, 2017). Similarly, no variable in the framework necessitate a certain type of organization and work setting therefore using convenience sampling technique may not be an issue of concern. Questionnaires were distributed among 1100 respondents of Rawalpindi and Islamabad within three months duration starting from March 2017. After deleting the responses with missing values and outliers, 519 useable responses were finally used for further analysis thus yielding effective response rate of $47.11 \%$. In order to observe the non-response bias, a statistical procedure was followed to compare the responses of sample (Armstrong \& Overton, 1977). No statistical differences were observed between the data collected related to variables of study from early respondents and late respondents which is an indication of absence of nonresponse bias. Outliers and responses with missing values were removed from the final dataset. Univariate outliers were identified by using the graphical technique in SPSS i.e. boxplot. Multivariate outliers were identified by using the Cook's distance test (Cook, 1977). Influential records identified during Cook's distance test with values greater than threshold i.e. 1.00 (Cook \& Weisberg, 1982) were deleted from the final dataset. Final sample size was in line with the directions given by several authors (Boomsma, 1983; Hair, Black, Babin, Anderson, \& Tatham, 2006). The correlation between the variables of study was found less than 0.70 (see table 2) indicat- 
ing the absence of multicollinearity issues (Suki, 2016). Similarly, the value of VIF for each variable of study was found less than 3.3 which is also an indication of absence of multicollinearity issues in final dataset (Picón, Castro, \& Roldán, 2014). Normality of final dataset was assessed by observing the value of Skewness and Kurtosis. Data could be observed as extremely non-normal when the value of Skewness and Kurtosis is found greater than 2 and 7 respectively (Boomsma \& Hoogland, 2001). For current study, both Skewness and Kurtosis were found within acceptable range i.e. \pm 2 (Ryu, 2011).

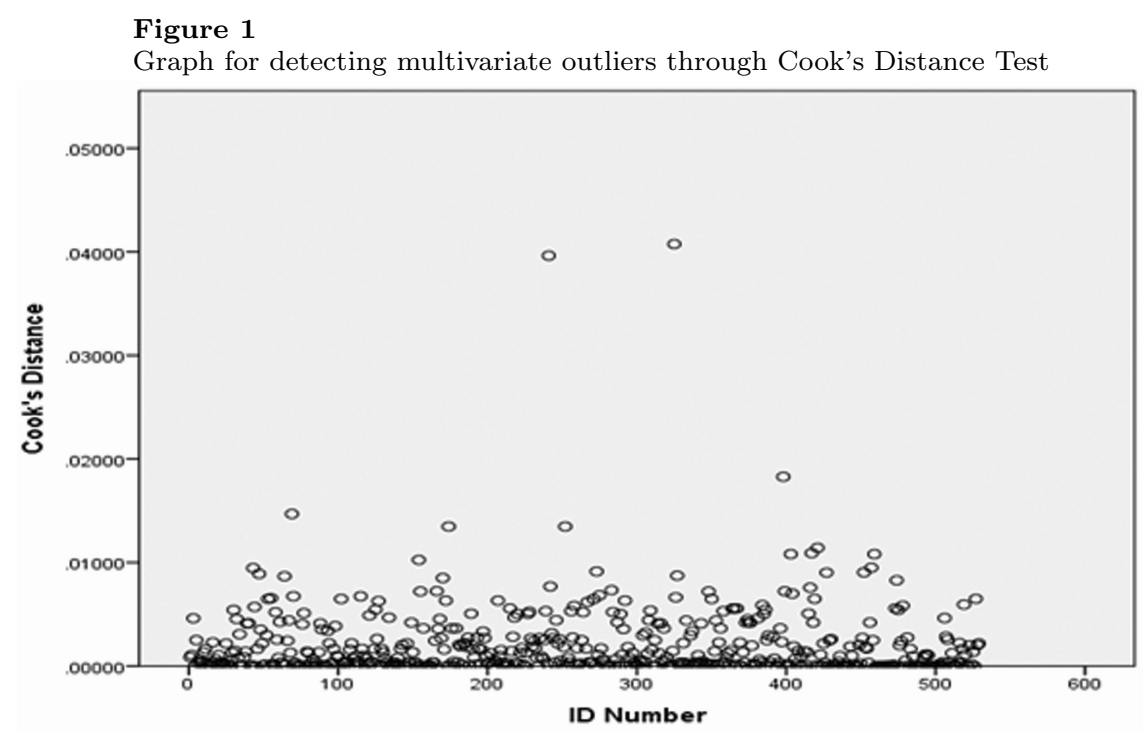

Data reveals that $68.7 \%$ of the respondents are male while $33.3 \%$ of the respondents are female. $53.9 \%$ respondents of the study are reported that they are married while $46.1 \%$ respondents of the study reported that they are un-married. Majority of the respondents i.e. $51.8 \%$ were master degree holder. Further, $36.5 \%$ respondents reported their age between 27 to 32 years. $33.8 \%$ respondents of the study reported their age less than 27 years while $29.7 \%$ respondents of the study reported their age greater than 32 years. Likewise, $39.7 \%$ respondents reported their working experience less than 4 years. $32.9 \%$ respondents of the study reported their working experience between 4 to 9 years while $27.4 \%$ respondents of the study reported their working experience greater than 9 years. Moreover, $52.2 \%$ respondents of the study reported their monthly salary ranged from Rs. 25,000 to Rs. 75,000 . Table 1 provides the demographic characteristics of final dataset used for further analysis. 
Table 1

\begin{tabular}{|c|c|c|c|c|}
\hline \multicolumn{5}{|l|}{ Gender } \\
\hline Male & \multicolumn{4}{|l|}{ Female } \\
\hline 66.7 & \multicolumn{4}{|l|}{33.3} \\
\hline \multicolumn{5}{|c|}{ Marital Status } \\
\hline Married & \multicolumn{4}{|l|}{ Single } \\
\hline 53.9 & 46.1 & & & \\
\hline \multicolumn{5}{|l|}{ Age } \\
\hline$<27$ years & 27 to 32 years & $>32$ years & & \\
\hline 33.8 & 36.5 & 29.7 & & \\
\hline \multicolumn{5}{|l|}{ Experience } \\
\hline$<4$ Years & 4 to 9 Years & $>9$ Years & & \\
\hline 39.7 & 32.9 & 27.4 & & \\
\hline \multicolumn{5}{|l|}{ Education } \\
\hline 12/13 Years & 14/15/16 Years & 17/18 Years & Above 18 Years & \\
\hline 3.6 & 36.7 & 51.8 & 7.9 & \\
\hline \multicolumn{5}{|c|}{ Income (Pak. Rs.) } \\
\hline$<25000$ & 25,000 to 50,000 & 51,000 to 75,000 & 76,000 to 100,000 & $>100,000$ \\
\hline 22.5 & 32.9 & 19.3 & 15.9 & 9.5 \\
\hline
\end{tabular}

Table 2 provides the means, standard deviations, correlations and reliabilities of the study variables. Environmental beliefs was significantly and positively related to environmental concern $(\mathrm{r}=.24, \mathrm{p}<.01)$ and green purchase intentions $(\mathrm{r}=.12, \mathrm{p}<.05)$. Furthermore, environmental concern was significantly and positively related to green purchase intentions $(\mathrm{r}=.25, \mathrm{p}<.01)$.

Table 2

Descriptive Statistics, Reliabilities and Inter-correlations

\begin{tabular}{lccccc}
\hline Variables & Mean & SD & $\mathbf{1}$ & $\mathbf{2}$ & $\mathbf{3}$ \\
\hline Environmental Beliefs & 2.47 & 1.11 & -0.88 & & \\
Environmental Concern & 3.82 & 1.13 & $0.24^{* *}$ & -0.88 & \\
Green Purchase Intentions & 4.67 & 1.38 & $0.12^{*}$ & $0.25^{* *}$ & -0.94 \\
\hline $\mathrm{N}=519 ;$ Alpha reliabilities are in parenthesis on the diagonal; & ${ }^{*} \mathrm{p}<.05$, \\
$* * \mathrm{p}<.01$ & & & &
\end{tabular}

\section{Measures}

All measures for current study were adopted from the prior research due to their established validity and reliability. Responses were measured on 7-Points likert scale ranging from (1) 'strongly disagree' to (7) 'strongly agree'. The value of Cronbach's alpha for all measuring scales used for current study was found greater than 0.7 which is considered to be an acceptable level (Lance, Butts, \& Michels, 2006).

To measure environmental beliefs, seven items scale developed by Kilbourne and Pickett (2008) was adopted. Sample items include "Different types of pollution are rising to dangerous levels"; "Shortages of some important resources will occur in the near future"; "The availability of clean water will become a problem in the near future,". The Cronbach's alpha of was found to be 0.87 .

To measure the environmental concern, seven items scale was used in which four items were found common and adapted from the studies of (Aman, Harun, \& Hussein, 2012; LingYee, 1997) and further, three items were adopted from the study of Lee (2009). Sample 
items include "I become angry when I think about harm being done to environment by pollution"; "When I think of the ways industries are causing pollution, I get frustrated and angry"; "I become incensed when I think about the harm being done to planet and life by pollution," and "I often think about how the environmental quality in Pakistan can be improved". The Cronbach's alpha is 0.87 .

To measure the consumer green purchase intentions, three items scale was adapted from the study of Mei, Ling, and Piew (2012). One more items was adapted from the study of Chan and Lau (2000). Sample items include "I would consider buying those products that are environmental friendly"; "I would intend to buy those products that are environmental friendly"; "I would buy those products that are not harmful to the environment," and "I would plan to buy those products that are environmental friendly". The value of Cronbach's alpha of four items scale used for current study to measure the green purchase intentions was found .94. All statistical analysis were performed by using the Statistical Package for the Social Sciences (SPSS) Version 23 and Analysis of a Moment Structures (AMOS) Version 23. Both softwares are widely used for data analysis in social sciences research.

\section{Exploratory Factor Analysis}

Exploratory factor analysis (EFA) was used to assure the accuracy of measurement constructs and to confirm the presentence of an expected structure in observed variables (Barrett, 1972; Royne, Martinez, Oakley, \& Fox, 2012) because multiple scales were found in prior research to measure the variables of study.

Table 3

Exploratory Factor Analysis

\begin{tabular}{lccc}
\hline \multicolumn{3}{c}{ Pattern Matrix } \\
\hline & \multicolumn{3}{c}{ Factors } \\
\hline EB_1 & 0.84 & & \\
EB_2 & 0.82 & & \\
EB_3 & 0.67 & & \\
EB_4 & 0.59 & & \\
EB_5 & 0.73 & & \\
EB_6 & 0.78 & 0.63 & \\
EB_7 & 0.57 & 0.67 & \\
EC_1 & 0.79 & \\
EC_2 & 0.77 & \\
EC_3 & & & \\
EC_4 & & 0.72 & \\
EC_5 & 0.76 & \\
EC_6 & & & \\
EC_7 & & & \\
GPI_1 & & \\
GPI_2 & & \\
GPI_3 & & \\
GPI_4 & & \\
\hline Extraction Method: Maximum Likelihood. & \\
Rotation Method: Promax with Kaiser Normalization. & \\
a. Rotation converged in 5 iterations. &
\end{tabular}


The decision whether the dataset is viable for EFA depends on the values of Kaiser-MeyerOlkin (KMO) and Bartlett's test of Sphericity. The value of $\mathrm{KMO} \geq 0.8$ for current study i.e. 0.86 and value of $\mathrm{p} \leq .05$ for Bartlett's test confirmed the adequacy of sample (Zinkhan \& Carlson, 1995) indicating that there exist significant correlations among the items of observed variables of study. By using the maximum likelihood extraction method augmented by Promax with Kaiser Normalization, three factors were extracted (table 3 ). The loadings of all items of each observed variable is greater than minimum cutoff value i.e. 0.40 (Kucukusta, Mak, \& Chan, 2013). The total variance explained by the three-factor model was $59 \%$ with eigenvalue greater than 1.0 for each extracted factor.

\section{Confirmatory Factor Analysis}

Confirmatory factor analysis (CFA) was used to assess the validity of 3-factor measurement model comprising of environmental beliefs, environmental concern and green purchase intentions (table 4). During CFA, all items loading for each construct was found greater than 0.5 . The values of fit indices revealed good model fit for hypothesized model $\left(\chi^{2}=154.51\right.$; $\mathrm{DF}=121 ; \mathrm{CFI}=0.99 ; \mathrm{SRMR}=0.03 ; \mathrm{RMSEA}=0.02 ; \mathrm{PClose}=1.00)$. The value of Average Variance Extracted (AVE) and Composite Reliability for all variables of study was found greater than 0.50 and 0.70 respectively which demonstrate the sufficient convergent validity (Chen \& Chang, 2012; Yap \& Khong, 2006).

\section{Common Method Bias}

The data for all variables of study was collected by using self-reported survey method.

Table 4

Constructs, Items, Loadings, Convergent Validity

\begin{tabular}{|c|c|c|c|c|}
\hline Constructs & Items & $\lambda 1^{*} / \lambda 2^{* *}$ & CR1* / CR2** & AVE1* / AVE1** \\
\hline \multirow[t]{7}{*}{ Environmental Beliefs } & EB_1 & $0.81 / 0.79$ & $0.87 / 0.87$ & $0.51 / 0.50$ \\
\hline & EB_2 & $0.78 / 0.75$ & & \\
\hline & EB_3 & $0.67 / 0.68$ & & \\
\hline & EB_4 & $0.61 / 0.60$ & & \\
\hline & EB_5 & $0.68 / 0.68$ & & \\
\hline & EB_6 & $0.77 / 0.76$ & & \\
\hline & EB_7 & $0.60 / 0.61$ & & \\
\hline \multirow[t]{7}{*}{ Environmental Concern } & EC_1 & $0.67 / 0.67$ & $0.89 / 0.89$ & $0.55 / 0.53$ \\
\hline & EC_2 & $0.68 / 0.68$ & & \\
\hline & EC_3 & $0.86 / 0.83$ & & \\
\hline & EC_4 & $0.74 / 0.71$ & & \\
\hline & EC_5 & $0.66 / 0.65$ & & \\
\hline & EC_6 & $0.81 / 0.79$ & & \\
\hline & EC_7 & $0.74 / 0.74$ & & \\
\hline \multirow[t]{4}{*}{ Green Purchase Intentions } & GPI_1 & $0.82 / 0.82$ & $0.94 / 0.93$ & $0.78 / 0.78$ \\
\hline & GPI_2 & $0.90 / 0.90$ & & \\
\hline & GPI_3 & $0.97 / 0.97$ & & \\
\hline & GPI_4 & $0.84 / 0.83$ & & \\
\hline
\end{tabular}

Therefore, statistical method suggested by Podsakoff, MacKenzie, Lee, and Podsakoff 
(2003) was used to check whether the results of measurement model are affected due to common method bias. According to this method the relationship of an "unmeasured latent factor" was created with all items of measurement model. No major difference in the values of regression coefficients $(\lambda)$, AVE and CR obtained after the inclusion of Common Latent Factor "CLF" in our measurement model. Similarly, the values of CR and AVE remained greater than or equal to the minimum threshold for all constructs i.e. 0.7 and 0.5 respectively indicating the adequacy of data for further analysis (table 4 ).

\section{Hypothesis Testing Using Structure Equation Modeling (SEM)}

All pre-requisite statistical tests suggested by Hair et al. (2006) exhibit the acceptable results which let the researchers to use structural equation modeling to test the proposed hypothesis of the study. Sample size was found to be adequate. Final dataset pertain no outliers and missing values. Similarly, normality, validity and multicollinearity were not an issue of concern for current study. Finally, values of fit indices revealed good model fit for conceptual model $\left(\chi^{2}=188.67 ; \mathrm{DF}=136 ; \mathrm{CFI}=0.99 ; \mathrm{SRMR}=0.04 ; \mathrm{RMSEA}=0.03\right.$; PClose $=1.00)$. The value of standardized coefficient $(\beta)$ for structural path from environmental beliefs to green purchase intentions was significant and positive $(\beta=0.11, \mathrm{p}<0.001)$. Thus, H1 was supported. Similarly, the value of standardized coefficient $(\beta)$ for structural path from environmental beliefs to environmental concern was significant and positive $(\beta=0.25, \mathrm{p}<0.001)$. Thus, $\mathrm{H} 2$ was supported. Similarly, the value of standardized coefficient $(\beta)$ for structural path from environmental concern to green purchase intentions $(\beta=0.25, \mathrm{p}<0.001)$ was found positive and significant. Thus, H3 was also supported. The value of multiple squared correlations $\left(R^{2}=.07 \& .06\right)$ revealed that $7 \% \& 6 \%$ variation in green purchase intentions and environmental concern respectively.

Table 5

Results - Hypothesis testing using structural equation modeling

\begin{tabular}{lcccccc}
\hline Hypotheses & Description & $\beta$ & S.E & t- value & Sig. & Results \\
\hline H1 & E. $B \rightarrow$ G.P.I & 0.11 & 0.03 & 3.77 & 0.01 & accepted \\
H2 & E.B $\rightarrow$ E.C & 0.25 & 0.02 & 3.51 & 0.00 & accepted \\
H3 & E.C $\rightarrow$ G.P.I & 0.25 & 0.06 & 3.59 & 0.00 & accepted \\
\hline $\mathrm{N}=519$, Arrow indicates the direction of impact.
\end{tabular}

Bootstrapping technique was used to test the mediation effect through analyzing the direct and indirect effects (Shrout \& Bolger, 2002) instead of using traditional method suggested by Baron and Kenny. This approach is considered more appropriate to test the mediation effects because it does not impose the assumption of normality and provides more accurate confidence intervals (Newton, Tsarenko, Ferraro, \& Sands, 2015). In bootstrapping technique, multiple samples are drawn from the dataset with replacement to apply the statistical tests. Bootstrapping technique possess high statistical power and therefore could be used for small sample size also (Zhang \& Wang, 2008). To test the mediating role of environmental concern between environmental beliefs and green purchase intentions, 2000 bootstrap samples were extracted with $95 \%$ bias-corrected confidence interval. The results revealed (Fig. 2) that the relationship between environmental beliefs (independent variable) and green purchase intentions (dependent variable) became insignificant $(\beta=.05$, 
$\mathrm{p}=$ n.s.) in presence of environmental concern. In the same line, the indirect effect of environmental beliefs on green purchase intentions was found significant i.e. $=0.03(95 \% \mathrm{CI}$ : $0.03 \sim 0.11$ ) indicating that environmental concern mediates between the environmental beliefs and green purchase intentions. Thus, H4 was fully supported.

Table 6

Values of Measures used to gauge the Model Fit

\begin{tabular}{lccccccc}
\hline Measure & CMIN & DF & CMIN/DF & CFI & SRMR & RMSEA & PCLOSE \\
\hline Estimate & 188.67 & 136 & 1.39 & 0.99 & 0.04 & 0.03 & 1 \\
Threshold & - & - & Between 1 and 3 & $>0.95$ & $<0.08$ & $<0.06$ & $>0.05$ \\
\hline
\end{tabular}

Figure 2

Structural Model Containing EC as a Mediating variable between EB and GPI

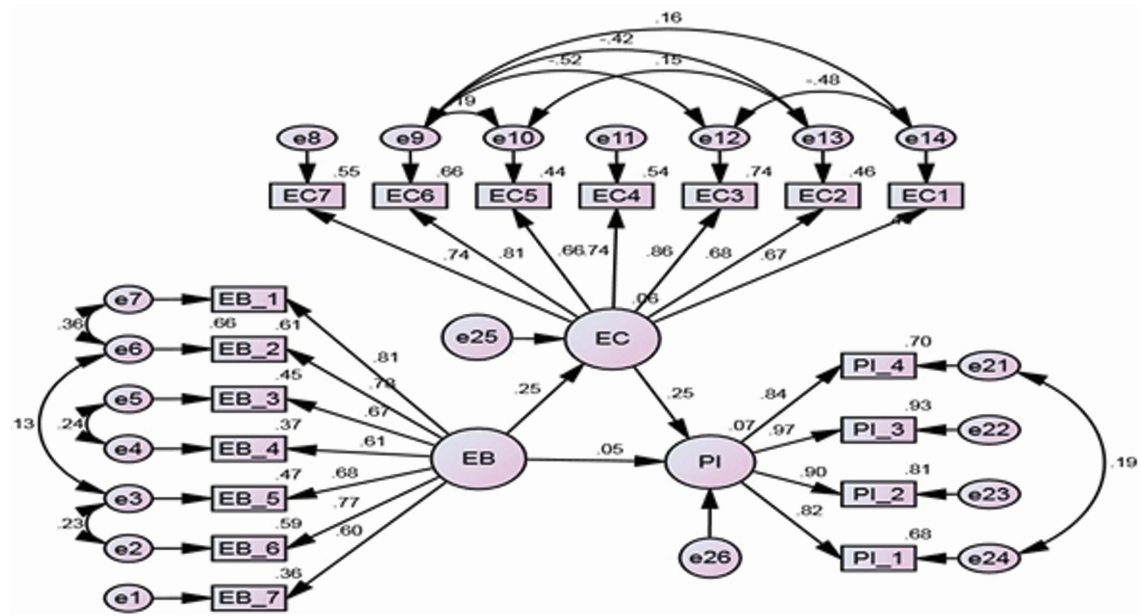

\section{Discussion}

The research in the field of green marketing is continuously growing to enrich the pool of knowledge with findings from different cultures and geographical regions to reduce the attitude-behavior gap. The current study was also an effort to participate in the ongoing stream of research by investigating the relationship among certain attitudinal variables such as environmental beliefs, environmental concern and green purchase intentions in an Asian context. Different statistical techniques were applied on data collected from 519 respondents to examine the proposed relationships in the conceptual model. The results of EFA revealed the presence of an expected structure in observed variables. Similarly, discriminant validity and convergent validity of constructs in the measurement model was confirmed by using CFA. The results obtained through SEM confirm the effect of environmental beliefs on environmental concern and green purchase intentions. Similarly, the results revealed the effect of environmental concern on green purchase intentions. Overall, these findings are consistent with the prior research conducted by several authors in the field of green marketing. 
Although, the results proved a direct and indirect effect of environmental beliefs on green purchase intentions however direct relationship between environmental beliefs and green purchase intentions was found quite weak. These results are consistent with the findings of prior research such as Pickett-Baker and Ozaki (2008). Other studies are also available which have highlighted environmental beliefs as a significant variable to promote green consumption behaviors (D'Souza et al., 2007; Pagiaslis \& Krontalis, 2014). The weak relationship between environmental beliefs and green purchase intentions in current study might be due to low level of environmental beliefs (mean $=2.47$ ) demonstrated by the respondents of study. However, the inclusion of environmental concern as a mediating variable between environmental beliefs and green purchase intention in the conceptual model suddenly changed the results. The findings suggest that environmental beliefs are an antecedent of environmental concern which has significant impact on consumer green purchase intentions. The stronger role of mediating variable between environmental beliefs and green purchase intentions is in line with the directions provided by authors in prior studies (Corral-Verdugo et al., 2003; Gadenne et al., 2011).

The results also reveal a significant correlation between environmental beliefs and environmental concern. These results are consistent with the findings of prior research (Kilbourne \& Pickett, 2008). However, few studies such as Bang et al. (2000) can also be found in literature in which a weak relationship between environmental beliefs and environmental concern has been reported. Similarly, in prior studies it was highlighted by certain authors that even consumers with high environmental concern are not practically involved in green purchases (Manaktola \& Jauhari, 2007; Newton et al., 2015). Such finding refers towards the identification of strong antecedent of environmental concern (Mostafa, 2007). Current study has taken environmental beliefs as an antecedent of environmental concern. The results also proved significant association between environmental beliefs and environmental concern.

The findings of this research study depicts that environmental concern has a significant impact on green purchase intentions. The results are consistent with the findings of prior research in which authors have highlighted environmental concern as a significant predictor of green purchase intentions (Dunlap \& Van Liere, 1978; Griskevicius et al., 2010; Pagiaslis \& Krontalis, 2014). However, few studies are also available which have reported environmental concern as a weak predictor of green purchase intentions (Bamberg, 2003; Han \& Kim, 2010). Overall, environmental concern is reported to be a strong predictor of green purchase intentions in prior research. The results of current study also support the notion that consumers with higher level of environmental concern are more likely to involve in green consumption behaviors.

\section{Conclusion}

Many organizations around the globe are in pressure to take in to account the best interest of the society and environment while developing their business strategies. Becoming green may be considered to be an expensive decision if the response of consumers is not controlled through proper communication strategies. The argument is supported by many 
recent studies in which the authors are continuously highlighting a gap between predicted and actual demand of the green products in the real markets (Barbarossa \& Pastore, 2015; Gleim et al., 2013). The current study was an effort to enrich the existing pool of knowledge on green marketing by exploring the mediating role of environmental concern between environmental beliefs and green purchase intentions. The conceptual model was developed based on the theory of reasoned action and tested by using the Structure Equation Modeling bootstrapping technique. The result of the current study reveals that environmental concern fully mediates the relationship between environmental beliefs and green purchase intentions. The findings suggest that primary focus of marketing activities might be on improving the environmental beliefs of consumers. It will raise the environmental concern of consumers and consequently such consumers would be more inclined towards the purchase on green products.

\section{Managerial Implications}

Several managerial implications can be inferred from the results of study. The weak relationship between environmental beliefs and green purchase intentions implies the low level of environmental beliefs. In fact, there is lack of awareness among the population regarding the environmental hazards, its antecedents and consequences. The findings suggest that comprehensive marketing programs are needed to be prepared in order to create awareness regarding the effects of environmental degradation issues on human life (Hannibal, Liu, \& Vedlitz, 2016; Nath et al., 2013) so that environmental beliefs can be strengthen. The result of prior research studies reveal that residents of a specific geographical region may be aware about the environmental hazards (e.g. global warming, shortage of clean water, energy crisis) which are visible to them or effects are directly felt, whereas, some of the environmental degradation issues may be more dangerous however may not be visible to general public (Schultz et al., 2014). Therefore, primarily, environmental awareness programs may give more attention to local environmental problems which are approaching to dangerous levels (Hannibal et al., 2016) to strengthen the environmental beliefs of general public (J. Liu et al., 2007).

The mediating role of environmental concern between environmental beliefs and green purchase intentions requires special attention and understanding. According to prior research, consumers with higher level of environmental concern could be an attractive target market segment to serve with green products because such consumers may require less efforts to get involved in green consumption behaviors (Nath et al., 2013). The significant relationship between environmental beliefs and environmental concern indicates that it is pre-requisite to improve the environmental beliefs in order to raise the environmental concern of consumers.

According to the results of current research study, the mean value obtained for environmental beliefs is lower as compare to other variables of the study (see table 2). These findings suggest a greater need to improve the environmental beliefs of consumers although changing environmental beliefs may take a long time in some countries (McDonald, Oates, Thyne, Timmis, \& Carlile, 2015). In this regard, marketing managers may use a combination of promotion mix strategies. Especially, effective use of social media could be very 
helpful in strengthening the environmental beliefs and environmental concern of population (Dagher \& Itani, 2014). Opinion leaders could also be very helpful in social media campaigns (Yu, Yu, \& Chao, 2017) to grasp the attention of potential consumers towards the environmental degradation issues and the need to adopt green consumption behaviors. However, marketing managers must be careful while selecting the opinion leaders for such advertising campaigns which are developed to improve the environmental beliefs and environmental concern of population.

The findings of current research although confirm the effects of environmental beliefs and environmental concern on consumer green purchase intentions. However, according to prior research, marketing manager must also keep in mind that environmental beliefs and environmental concern of consumers might not be translated in to green purchase intentions if consumers have lack of information regarding green products (Pagiaslis \& Krontalis, 2014). Therefore, marketing managers should also focus on creating awareness of green products in the market place through print and electronic media.

\section{Limitations and Future Research Directions}

Like other studies, there were several limitations which were taken in to consideration while addressing the conceptual model of the study empirically. These limitations could be an opportunity for researchers which are interested to explore the area of green marketing. First, it should be noted that emphasis of current research was to measure and explain the variables which might influence the consumers' environmental concern and ultimately their green purchase intentions. Intentions are only considered to be the proximal of actual behavior and therefore results might be different when consumers are provided an opportunity to make a decision in real world. To overcome this gap, longitudinal studies might be helpful to observe the original behaviors of customers. Second, current study has adopted most widely used survey method in social science i.e. questionnaire for data collection. However, future studies may use alternative survey methods such as observation, focus group or experimental design in order to identify the natural behavior of customers. Such findings may be more helpful for marketing managers in developing effective green marketing strategies. Third, multiple scales were found in literature to measure the environmental beliefs and environmental concern of consumers. Future studies may focus on developing generalized scales which can be used in different countries and cultures to increase the generalizability of results. Fourth, the sample of current study may not be a true representative of whole population because of using convenience sampling technique. More biased response was expected from the respondents of study however it didn't happen in actual. The results revealed a weak relationship between environmental beliefs and green purchase intentions which demand further attention in future research studies. Researchers may identify and explore the role of other moderating and mediating variables which are hampering the direct effect of environmental beliefs on green purchase intentions. These studies could be qualitative in nature followed by quantitative techniques to provide better understanding and practical implications for marketing managers. Fifth, the low mean value of environmental beliefs may also be an issue of concern. However, future research studies may identify antecedents which could predict the environmental beliefs of 
public. Such studies may also focus on the ways through which marketing managers could strengthen the environmental beliefs of consumers to achieve desired goals and objectives. 


\section{References}

Akehurst, G., Afonso, C., \& Martins Gonçalves, H. (2012). Re-examining green purchase behaviour and the green consumer profile: New evidences. Management Decision, $50(5), 972-988$.

Aman, A. L., Harun, A., \& Hussein, Z. (2012). The influence of environmental knowledge and concern on green purchase intention the role of attitude as a mediating variable. British Journal of Arts and Social Sciences, 7(2), 145-167.

Anderson, B. A., Romani, J. H., Phillips, H. E., Wentzel, M., \& Tlabela, K. (2006). Exploring perceptions, behaviors and awareness: Water and water pollution in South Africa. Population and Environment, 28(3), 133-161.

Armstrong, J. S., \& Overton, T. S. (1977). Estimating nonresponse bias in mail surveys. Journal of Marketing Research, 396-402.

Bamberg, S. (2003). How does environmental concern influence specific environmentally related behaviors? A new answer to an old question. Journal of Environmental Psychology, 23(1), 21-32.

Bang, H.-K., Ellinger, A. E., Hadjimarcou, J., \& Traichal, P. A. (2000). Consumer concern, knowledge, belief, and attitude toward renewable energy: An application of the reasoned action theory. Psychology \& Marketing, 17(6), 449-468.

Barbarossa, C., \& Pastore, A. (2015). Why environmentally conscious consumers do not purchase green products: A cognitive mapping approach. Qualitative Market Research: An International Journal, 18(2), 188-209.

Barber, N. (2010). "Green" wine packaging: Targeting environmental consumers. International Journal of Wine Business Research, 22(4), 423-444.

Barrett, G. V. (1972). Research models of the future for industrial and organizational psychology. Personnel Psychology, 25(1), 1-17.

Biswas, A., \& Roy, M. (2015). Green products: an exploratory study on the consumer behaviour in emerging economies of the East. Journal of Cleaner Production, 87, 463-468.

Boomsma, A. (1983). On the robustness of lisrel (maximum likelihood estimation) against small sample size and non-normality (Unpublished doctoral dissertation). Rijksuniversiteit Groningen.

Boomsma, A., \& Hoogland, J. J. (2001). The robustness of lisrel modeling revisited. Structural equation models: Present and future. A Festschrift in honor of Karl Jöreskog, 2(3), 139-168.

California-Green-Solutions. (2007). Green consumer research outlines the challenge. Retrieved from http://www.californiagreensolutions.com

Chan, R. Y., \& Lau, L. B. (2000). Antecedents of green purchases: A survey in China. Journal of Consumer Marketing, 17(4), 338-357.

Chen, Y.-S. (2010). The drivers of green brand equity: Green brand image, green satisfaction, and green trust. Journal of Business Ethics, 93(2), 307-319.

Chen, Y.-S., \& Chang, C.-H. (2012). Enhance green purchase intentions: The roles of green perceived value, green perceived risk, and green trust. Management Decision, $50(3), 502-520$. 
Chen, Y.-S., \& Chang, C.-H. (2013). Greenwash and green trust: The mediation effects of green consumer confusion and green perceived risk. Journal of Business Ethics, $114(3), 489-500$.

Cherian, J., \& Jacob, J. (2012). Green marketing: A study of consumers' attitude towards environment friendly products. Asian Social Science, 8(12), 117-126.

Cook, R. D. (1977). Detection of influential observation in linear regression. Technometrics, $19(1), 15-18$.

Cook, R. D., \& Weisberg, S. (1982). Residuals and influence in regression. New York: Chapman and Hall.

Cooney, S. (2010). Lohas releases annual consumer trend database. In The Annual LOHAS Conference.

Corral-Verdugo, V., Bechtel, R. B., \& Fraijo-Sing, B. (2003). Environmental beliefs and water conservation: An empirical study. Journal of Environmental Psychology, 23(3), $247-257$.

Cowan, K., \& Kinley, T. (2014). Green spirit: Consumer empathies for green apparel. International Journal of Consumer Studies, 38(5), 493-499.

Cronin Jr, J. J., Brady, M. K., \& Hult, G. T. M. (2000). Assessing the effects of quality, value, and customer satisfaction on consumer behavioral intentions in service environments. Journal of Retailing, 76(2), 193-218.

Dagher, G. K., \& Itani, O. (2014). Factors influencing green purchasing behaviour: Empirical evidence from the Lebanese consumers. Journal of Consumer Behaviour, 13(3), $188-195$.

Davari, A., \& Strutton, D. (2014). Marketing mix strategies for closing the gap between green consumers' pro-environmental beliefs and behaviors. Journal of Strategic Marketing, 22(7), 563-586.

Do Paco, A., \& Raposo, M. (2009). "Green" segmentation: An application to the Portuguese consumer market. Marketing Intelligence \& Planning, 27(3), 364-379.

D'Souza, C., Taghian, M., \& Khosla, R. (2007). Examination of environmental beliefs and its impact on the influence of price, quality and demographic characteristics with respect to green purchase intention. Journal of Targeting, Measurement and Analysis for Marketing, 15(2), 69-78.

D'Souza, C., Taghian, M., Sullivan-Mort, G., \& Gilmore, A. (2015). An evaluation of the role of green marketing and a firm's internal practices for environmental sustainability. Journal of Strategic Marketing, 23(7), 600-615.

Dunlap, R. E., et al. (1994). International attitudes towards environment and development. Green globe yearbook of international co-operation on environment and development, $1994,115-126$.

Dunlap, R. E., \& Van Liere, K. D. (1978). The "new environmental paradigm". The Journal of Environmental Education, 9(4), 10-19.

Euromonitor-International. (2012). Green buying behaviour: Global online survey. Retrieved from www.portal.euromonitor.com

Fetterman, M. (2006). Wal-mart grows 'green' strategies. USA Today, 9(25).

Fishbein, M., \& Ajzen, I. (1975). Belief, attitude, intention and behavior: An introduction to theory and research. In: Reading, MA: Addison-Wesley. 
Follows, S. B., \& Jobber, D. (2000). Environmentally responsible purchase behaviour: A test of a consumer model. European Journal of Marketing, 34(5/6), 723-746.

Gadenne, D., Sharma, B., Kerr, D., \& Smith, T. (2011). The influence of consumers' environmental beliefs and attitudes on energy saving behaviours. Energy $p=$ Policy, $39(12), 7684-7694$.

Gleim, M. R., Smith, J. S., Andrews, D., \& Cronin Jr, J. J. (2013). Against the green: A multi-method examination of the barriers to green consumption. Journal of Retailing, $89(1), 44-61$.

González, E. M., Felix, R., Carrete, L., Centeno, E., \& Castaño, R. (2015). Green shades: A segmentation approach based on ecological consumer behavior in an emerging economy. Journal of Marketing Theory and Practice, 23(3), 287-302.

Grewal, D., \& Levy, M. (2008). Marketing. Boston: MA: McGraw-Hill.

Grimmer, M., \& Woolley, M. (2014). Green marketing messages and consumers' purchase intentions: Promoting personal versus environmental benefits. Journal of Marketing Communications, 20(4), 231-250.

Griskevicius, V., Tybur, J. M., \& Van den Bergh, B. (2010). Going green to be seen: Status, reputation, and conspicuous conservation. Journal of Personality and Social Psychology, 98(3), 392. doi: 10.1037/a0017346

Guber, D. L. (2003). The grassroots of a green revolution: Polling America on the environment. MIT Press.

Ha, H.-Y., \& Janda, S. (2012). Predicting consumer intentions to purchase energy-efficient products. Journal of Consumer Marketing, 29(7), 461-469.

Hair, J. F., Black, W. C., Babin, B. J., Anderson, R. E., \& Tatham, R. L. (2006). Multivariate data analysis. Uppersaddle River: Pearson Prentice Hall.

Han, H., \& Kim, Y. (2010). An investigation of green hotel customers' decision formation: Developing an extended model of the theory of planned behavior. International Journal of Hospitality Management, 29(4), 659-668.

Hannibal, B., Liu, X., \& Vedlitz, A. (2016). Personal characteristics, local environmental conditions, and individual environmental concern: A multilevel analysis. Environmental Sociology, 2(3), 286-297.

Harris, P. G. (2006). Environmental perspectives and behavior in China: Synopsis and bibliography. Environment and Behavior, 38(1), 5-21.

Hartman, G. (2007). The hartman report on sustainability: Understanding the consumer perspective. In: Hartman Group Bellevue, WA.

Hughner, R. S., McDonagh, P., Prothero, A., Shultz, C. J., \& Stanton, J. (2007). Who are organic food consumers? A compilation and review of why people purchase organic food. Journal of Consumer Behaviour, 6(2-3), 94-110.

Johnstone, M.-L., \& Tan, L. P. (2015). An exploration of environmentally-conscious consumers and the reasons why they do not buy green products. Marketing Intelligence \& Planning, 33(5), 804-825.

Joshi, Y., \& Rahman, Z. (2015). Factors affecting green purchase behaviour and future research directions. International Strategic Management Review, 3(1-2), 128-143.

Kalafatis, S. P., Pollard, M., East, R., \& Tsogas, M. H. (1999). Green marketing and Ajzen's theory of planned behaviour: A cross-market examination. Journal of Con- 
sumer Marketing, 16(5), 441-460.

Kang, J., Liu, C., \& Kim, S.-H. (2013). Environmentally sustainable textile and apparel consumption: The role of consumer knowledge, perceived consumer effectiveness and perceived personal relevance. International Journal of Consumer Studies, 37(4), $442-452$.

Khan, M. A. (2016). Pakistan ranks eight among countries affected by climate change. Retrieved from https://tribune.com.pk/story/1034730/save-our-environment -pakistan-ranks-eight-among-countries-affected-by-climate-change/

Kilbourne, W., \& Pickett, G. (2008). How materialism affects environmental beliefs, concern, and environmentally responsible behavior. Journal of Business Research, $61(9), 885-893$.

Kim, Y., \& Choi, S. M. (2005). Antecedents of green purchase behavior: An examination of collectivism, environmental concern, and PCE. ACR North American Advances, 32, 592-599.

Knopman, D. S., Susman, M. M., \& Landy, M. K. (1999). Civic environmentalism: tackling tough land-use problems with innovative governance. Environment: Science and Policy for Sustainable Development, 41(10), 24-32.

Konuk, F. A., Rahman, S. U., \& Salo, J. (2015). Antecedents of green behavioral intentions: A cross-country study of Turkey, Finland and Pakistan. International Journal of Consumer Studies, $39(6), 586-596$.

Kucukusta, D., Mak, A., \& Chan, X. (2013). Corporate social responsibility practices in four and five-star hotels: Perspectives from hong kong visitors. International Journal of Hospitality Management, 34, 19-30.

Lance, C. E., Butts, M. M., \& Michels, L. C. (2006). The sources of four commonly reported cutoff criteria: What did they really say? Organizational Research Methods, $9(2)$, 202-220.

Laroche, M., Bergeron, J., \& Barbaro-Forleo, G. (2001). Targeting consumers who are willing to pay more for environmentally friendly products. Journal of Consumer Marketing, 18(6), 503-520.

Lee, K. (2009). Gender differences in Hong Kong adolescent consumers' green purchasing behavior. Journal of Consumer Marketing, 26(2), 87-96.

Leonidou, C. N., \& Skarmeas, D. (2017). Gray shades of green: Causes and consequences of green skepticism. Journal of Business Ethics, 144(2), 401-415.

Lin, C.-Y., \& Syrgabayeva, D. (2016). Mechanism of environmental concern on intention to pay more for renewable energy: Application to a developing country. Asia Pacific Management Review, 21(3), 125-134.

Ling-Yee, L. (1997). Effect of collectivist orientation and ecological attitude on actual environmental commitment: The moderating role of consumer demographics and product involvement. Journal of International Consumer Marketing, 9(4), 31-53.

Liu, J., Dietz, T., Carpenter, S. R., Folke, C., Alberti, M., Redman, C. L., .. Lubchenco, J. (2007). Coupled human and natural systems. AMBIO: A Journal of the Human Environment, 36(8), 639-649.

Liu, X., Wang, C., Shishime, T., \& Fujitsuka, T. (2012). Sustainable consumption: Green purchasing behaviours of urban residents in China. Sustainable Development, 20(4), 
293-308.

Lo, A. Y. (2016). National income and environmental concern: Observations from 35 countries. Public Understanding of Science, 25(7), 873-890.

Lung, S. (2010). Green consumerism-the way to effectively differentiate your products in Asia-Pacific market. Online Article, Retrieved January, 20, 2013.

Luo, X., \& Bhattacharya, C. B. (2006). Corporate social responsibility, customer satisfaction, and market value. Journal of Marketing, 70(4), 1-18.

Mainieri, T., Barnett, E. G., Valdero, T. R., Unipan, J. B., \& Oskamp, S. (1997). Green buying: The influence of environmental concern on consumer behavior. The Journal of Social Psychology, 137(2), 189-204.

Malhotra, N. K. (2007). Marketing research an applied orientation. Pearson Education India.

Manaktola, K., \& Jauhari, V. (2007). Exploring consumer attitude and behaviour towards green practices in the lodging industry in India. International Journal of Contemporary Hospitality Management, 19(5), 364-377.

Manget, J., Roche, C., \& Münnich, F. (2009). Capturing the green advantage for consumer companies. The Boston Consulting Group, 13.

McCarty, J. A., \& Shrum, L. (2001). The influence of individualism, collectivism, and locus of control on environmental beliefs and behavior. Journal of Public Policy \& Marketing, 20(1), 93-104.

McDonald, S., Oates, C. J., Thyne, M., Timmis, A. J., \& Carlile, C. (2015). Flying in the face of environmental concern: Why green consumers continue to fly. Journal of Marketing Management, 31(13-14), 1503-1528.

Mei, O. J., Ling, K. C., \& Piew, T. H. (2012). The antecedents of green purchase intention among Malaysian consumers. Asian Social Science, 8(13), 246-263.

Menguc, B., Auh, S., \& Ozanne, L. (2010). The interactive effect of internal and external factors on a proactive environmental strategy and its influence on a firm's performance. Journal of Business Ethics, 94 (2), 279-298.

Mina Okada, E., \& Mais, E. L. (2010). Framing the "green" alternative for environmentally conscious consumers. Sustainability Accounting, Management and Policy Journal, $1(2), 222-234$.

Moser, A. K. (2015). Thinking green, buying green? Drivers of pro-environmental purchasing behavior. Journal of Consumer Marketing, 32(3), 167-175.

Mostafa, M. M. (2007). A hierarchical analysis of the green consciousness of the Egyptian consumer. Psychology \& Marketing, 24(5), 445-473.

Namkung, Y., \& Jang, S. (2017). Are consumers willing to pay more for green practices at restaurants? Journal of Hospitality $\&$ Tourism Research, 41(3), 329-356.

Nath, V., Kumar, R., Agrawal, R., Gautam, A., \& Sharma, V. (2013). Consumer adoption of green products: Modeling the enablers. Global Business Review, 14(3), 453-470.

Newton, J. D., Tsarenko, Y., Ferraro, C., \& Sands, S. (2015). Environmental concern and environmental purchase intentions: The mediating role of learning strategy. Journal of Business Research, 68(9), 1974-1981.

Nguyen, T. N., Lobo, A., \& Greenland, S. (2017). Energy efficient household appliances in emerging markets: The influence of consumers' values and knowledge on their 
attitudes and purchase behaviour. International Journal of Consumer Studies, 41(2), $167-177$.

Nielsen. (2013). Will a desire to protect the environment translate into action? Retrieved from http://www.nielsen.com/us/en/newswire/2013/ will\&a\&desire\&to\&protect\&the\&environment\&translate\&into\&action\& . html

Oliver, J. D., \& Lee, S.-H. (2010). Hybrid car purchase intentions: A cross-cultural analysis. Journal of Consumer Marketing, 27(2), 96-103.

Olson, E. L. (2013). It's not easy being green: The effects of attribute tradeoffs on green product preference and choice. Journal of the Academy of Marketing Science, 41(2), 171-184.

Ozaki, R., \& Sevastyanova, K. (2011). Going hybrid: An analysis of consumer purchase motivations. Energy Policy, 39(5), 2217-2227.

Paço, A., \& Lavrador, T. (2017). Environmental knowledge and attitudes and behaviours towards energy consumption. Journal of Environmental Management, 197, 384-392.

Pagiaslis, A., \& Krontalis, A. K. (2014). Green consumption behavior antecedents: Environmental concern, knowledge, and beliefs. Psychology \& Marketing, 31 (5), 335-348.

Pickett-Baker, J., \& Ozaki, R. (2008). Pro-environmental products: marketing influence on consumer purchase decision. Journal of Consumer Marketing, 25(5), 281-293.

Picón, A., Castro, I., \& Roldán, J. L. (2014). The relationship between satisfaction and loyalty: A mediator analysis. Journal of Business Research, 67(5), 746-751.

Podsakoff, P. M., MacKenzie, S. B., Lee, J.-Y., \& Podsakoff, N. P. (2003). Common method biases in behavioral research: A critical review of the literature and recommended remedies. Journal of Applied Psychology, 88(5), 879-903.

Royne, M. B., Martinez, J., Oakley, J., \& Fox, A. K. (2012). The effectiveness of benefit type and price endings in green advertising. Journal of Advertising, 41(4), 85-102.

Ryu, E. (2011). Effects of skewness and kurtosis on normal-theory based maximum likelihood test statistic in multilevel structural equation modeling. Behavior Research Methods, 43(4), 1066-1074.

Saad, L. (2006). Americans see environment as getting worse. The Gallup Poll.

Schmeltz, L. (2012). Consumer-oriented csr communication: Focusing on ability or morality? Corporate Communications: An International Journal, 17(1), 29-49.

Schultz, P. W., Milfont, T. L., Chance, R. C., Tronu, G., Luís, S., Ando, K., .. Castro, J. (2014). Cross-cultural evidence for spatial bias in beliefs about the severity of environmental problems. Environment and Behavior, 46(3), 267-302.

Shrout, P. E., \& Bolger, N. (2002). Mediation in experimental and nonexperimental studies: New procedures and recommendations. Psychological Methods, 7(4), 422-445.

Sinnappan, P., \& Rahman, A. A. (2011). Antecedents of green purchasing behavior among Malaysian consumers. International Business Management, 5(3), 129-139.

Straughan, R. D., \& Roberts, J. A. (1999). Environmental segmentation alternatives: a look at green consumer behavior in the new millennium. Journal of Consumer Marketing, 16(6), 558-575.

Suki, N. M. (2016). Consumer environmental concern and green product purchase in Malaysia: Structural effects of consumption values. Journal of Cleaner Production, 132, 204-214. 
Thieme, J., Royne, M. B., Jha, S., Levy, M., \& Barnes McEntee, W. (2015). Factors affecting the relationship between environmental concern and behaviors. Marketing Intelligence \& Planning, 33(5), 675-690.

Tolliver-Nigro, H. (2009). Green market to grow 267 percent by 2015. Matter Network, 29.

Trafimow, D., \& Fishbein, M. (1994). The moderating effect of behavior type on the subjective norm-behavior relationship. The Journal of Social Psychology, 134(6), $755-763$.

Veisten, K. (2007). Willingness to pay for eco-labelled wood furniture: Choice-based conjoint analysis versus open-ended contingent valuation. Journal of Forest Economics, 13(1), 29-48.

Vermeir, I., \& Verbeke, W. (2008). Sustainable food consumption among young adults in Belgium: Theory of planned behaviour and the role of confidence and values. Ecological Economics, 64(3), 542-553.

Vezich, I. S., Gunter, B. C., \& Lieberman, M. D. (2017). The mere green effect: An fMRI study of pro-environmental advertisements. Social Neuroscience, 12(4), 400-408.

Widger, D. (2007). Green consumer behaviour-part 1: Information paradox. Marketing Green, 7.

Wire, N. (2011). The 'green' gap between environmental concerns and the cash register. Retrieved from http://www.nielsen.com.

Wray-Lake, L., Flanagan, C. A., \& Osgood, D. W. (2010). Examining trends in adolescent environmental attitudes, beliefs, and behaviors across three decades. Environment and Behavior, 42(1), 61-85.

Wu, J.-H., Wu, C.-W., Lee, C.-T., \& Lee, H.-J. (2015). Green purchase intentions: An exploratory study of the Taiwanese electric motorcycle market. Journal of Business Research, 68(4), 829-833.

Xiao, C., \& McCright, A. M. (2015). Gender differences in environmental concern: Revisiting the institutional trust hypothesis in the USA. Environment and Behavior, 47(1), 17-37.

Yap, B. W., \& Khong, K. W. (2006). Examining the effects of customer service management (CSM) on perceived business performance via structural equation modelling. Applied Stochastic Models in Business and Industry, 22(5-6), 587-605.

Young, W., Hwang, K., McDonald, S., \& Oates, C. J. (2010). Sustainable consumption: green consumer behaviour when purchasing products. Sustainable Development, 18(1), 20-31.

Yu, T.-Y., Yu, T.-K., \& Chao, C.-M. (2017). Understanding Taiwanese undergraduate students' pro-environmental behavioral intention towards green products in the fight against climate change. Journal of Cleaner Production, 161, 390-402.

Zhang, Z., \& Wang, L. (2008). Methods for evaluating mediation effects: Rationale and comparison. New Trends in Psychometrics, 595-604.

Zinkhan, G. M., \& Carlson, L. (1995). Green advertising and the reluctant consumer. Journal of Advertising, 24(2), 1-6. 